\title{
Determination of mercury in estuarine sediments by flow injection-cold vapour atomic absorption spectrometry after microwave extraction
}

\author{
M.L. Martínez-García, A. Carlosena*, P. López-Mahía, S. Muniategui and D. Prada \\ Dept. Analytical Chemistry, University of La Coruña, Campus A Zapateira s/n, E-15071 La Coruña, Spain
}

\begin{abstract}
A flow injection-cold vapour atomic absorption spectrometric (CVAAS) method was developed for the determination of mercury at trace level in estuarine sediments using sodium tetrahydroborate (III) as reductant. The mercury was solubilized with nitric acid in closed vessels and microwave oven heating. Instrumental and operational conditions (volume and concentration of reagents, reaction time, etc.) were optimized. The effect of several ions on the analytical signal was also studied; no interferences were recorded excepting for copper and nickel which caused a serious depressing effect. The detection limit obtained was $0.01 \mu \mathrm{g} \mathrm{g}^{-1}$. The validation of the method was performed analyzing a certified reference sediment, BCR CRM 277 Estuarine Sediment. Good recovery (c.a. 98\%) and precision (<3\%, RSD) were achieved. The proposed method was successfully applied to the determination of mercury in sediment samples from Ares-Betanzos Estuary (Galicia, NW Spain).
\end{abstract}

Key words. Mercury - CVAAS - sodium tetrahydroborate (III) - interferences - sediments.

\section{Introduction}

Due to the high toxicity of mercury and its compounds the analysis and monitoring of total mercury in environmental samples are extremely important. The inorganic mercury compounds both of natural and anthropogenic origins are characterized by chemical stability in sediments. In the marine environment take place several processes which can transform inorganic mercury to bioavailable organic form. Then, it is efficiently absorbed through biological membranes resulting in bioaccumulation [1].

Many different methods have been developed for the determination of inorganic and organic mercury at low concentrations in environmental samples. These instrumental methods are based on a wide range of techniques, such as neutron activation analysis (NAA) [2], cold vapour atomic fluorescence spectrometry (CVAFS) [3], gas chromatography-cold vapour atomic fluorescence spectrometry (GCCVAFS) [4], hydride generation inductively coupled plasma mass spectrometry (HG-ICPMS) [5], electrothermal atomization atomic absorption spectrometry (ETAAS) [6], and cold vapour generation atomic absorption spectrometry (CVAAS) [7,8]. The latter has received great attention for the determination of mercury because of its simplicity, high sensitivity and relative freedom from interferences. Since its early development in 1968 the method has been improved increasing the reliability and easiness of operation. Initially, tin (II) salts solutions were used to generate the mercury vapour. More recently, reduction with sodium tetrahydroborate (III) instead of tin (II) chloride has been widely used; the former is a strong reductant agent and it is able to reduce the mercury in most of its compounds, in contrast to the latter [9]. In general, there is agreement that the sodium tetrahydroborate (III) reduction is more rapid and may give better precision than the tin (II) chloride method [7].

The CVAAS technique is based on the reduction of mercury compounds present in samples to free metal, followed by transformation of the metal into atomic vapour which is measured [10]. It seems, therefore, that this technique should be free from interferences. The literature reports, however, that many elements as $\mathrm{Ag}, \mathrm{Au}, \mathrm{Pt}, \mathrm{Pd}, \mathrm{Cu}, \mathrm{Ni}, \mathrm{Pb}$ and $\mathrm{Se}$ significantly affect the mercury analytical signals [9-13].

The coupling of flow injection (FI) with cold vapour atomic absorption spectrometry (CVAAS) for the determination of mercury has many significant advantages in comparison with the conventional batch CVAAS technique. These advantages include lower sample and reagent consumption, higher sample throughput, easiness of automatization and lesser affected by metallic interferents (i.e., $\mathrm{Ni}$, $\mathrm{Cu}$ and $\mathrm{Ag}$ ) [14].

For the determination by CVAAS, mercury has to be present in its dissolved inorganic ionic species. Sample decomposition has to be done in such a way that the mercury present in the sample is completely brought into solution but avoiding any losses of the analyte. Due to the high volatility of mercury and its compounds, the employ of closed vessels for its extraction is essential. Moreover, its combination with microwave oven as heating source represents an

* Correspondence and reprints.

Received August 25, 1998; revised November 13, 1998; accepted December 3, 1998. 


\section{Original articles}

attractive alternative when samples as sediments must be analyzed $[15,16]$.

The aim of the present work was to develop a FI-CVAAS method for the reliable determination of mercury at trace level in estuarine sediments, after quantitative metal extraction with nitric acid in closed PTFE (polytetrafluoroethylene) vessels and microwave oven heating. Instrumental and operational conditions (volume and concentration of reagents, reaction time, etc.) were carefully optimized. The effect of several ions on the analytical signal was also studied.

\section{Experimental}

\section{Apparatus}

Measurements were made using a Flow Injection (FI) system, Varian VGA Model 76, interfaced to an atomic absorption spectrometer, Varian Model SpectrAA-10. All measurements were made at the $253.9 \mathrm{~nm} \mathrm{Hg}$ wavelength, using a $\mathrm{Hg}$ hollow-cathode lamp (Perkin-Elmer) and a bandwidth of $0.5 \mathrm{~nm}$. Nitrogen was used as carrier gas at a flow rate of $90 \mathrm{~mL} \mathrm{~min}^{-1}$.

The $\mathrm{Hg}$ extraction was performed using a laboratory microwave digestion system fitted with a Milestone microwave oven (Italy) MLS 1200 with a magnetron frequency of $2450 \mathrm{MHz}$ and a maximum power of $1000 \mathrm{~W}$, an automatic capping module ACM 100, and an exhaust module EM5. High pressure PTFE (polytetrafluoroethylene) vessels with a volume of $80 \mathrm{~mL}$ and pressure-relief valve were employed.

All plasticware and glassware were thoroughly cleaned by soaking for $24 \mathrm{~h}$ in $10 \% \mathrm{HNO}_{3}$ and rinsed with high purity water (Milli-Q system) at least three times.

\section{Reagents}

All reagents were of analytical grade. High purity water, resistivity $18 \mathrm{M} \Omega \mathrm{cm}^{-1}$, obtained from Milli-Q system of Millipore was employed throughout. The $\mathrm{Hg}$ stock solution (1000 mg L $\mathrm{m}^{-1}$ ) was obtained from Panreac (Spain). From this, working standard solutions containing appropriate amounts of $\mathrm{Hg}$ were daily prepared by serial dilution and acidified as well as samples. Nitric and chlorhydric acids were purchased from Merck. The $\mathrm{NaBH}_{4}$ solutions were freshly prepared by dissolving an adequate amount of powder (Merck) in $0.5 \%(\mathrm{~m} / \mathrm{v}) \mathrm{NaOH}$ solution, and filtered before used.

Solutions of the interfering species studied were prepared, using the same acid medium as the samples, by diluting stock solutions $\left(1000 \mathrm{mg} \mathrm{L}^{-1}\right)$ of: $\mathrm{Al}^{3+}, \mathrm{Ca}^{2+}, \mathrm{Co}^{2+}, \mathrm{Fe}^{3+}, \mathrm{K}^{+}$, $\mathrm{Mg}^{2+}, \mathrm{Mn}^{2+}, \mathrm{Na}^{+}, \mathrm{Pb}^{2+}, \mathrm{Zn}^{2+}, \mathrm{Cu}^{2+}, \mathrm{Ni}^{2+}, \mathrm{Cl}^{-}, \mathrm{CO}_{3}{ }^{2-}, \mathrm{NO}^{3-}$, $\mathrm{PO}_{4}{ }^{3-}$, and $\mathrm{SO}_{4}{ }^{2-}$.

\section{Sample preparation}

Sediment samples were frozen, freeze-dried, and sieved through a $2 \mathrm{~mm}$ and $1 \mathrm{~mm}$ mesh sieves, consecutively.

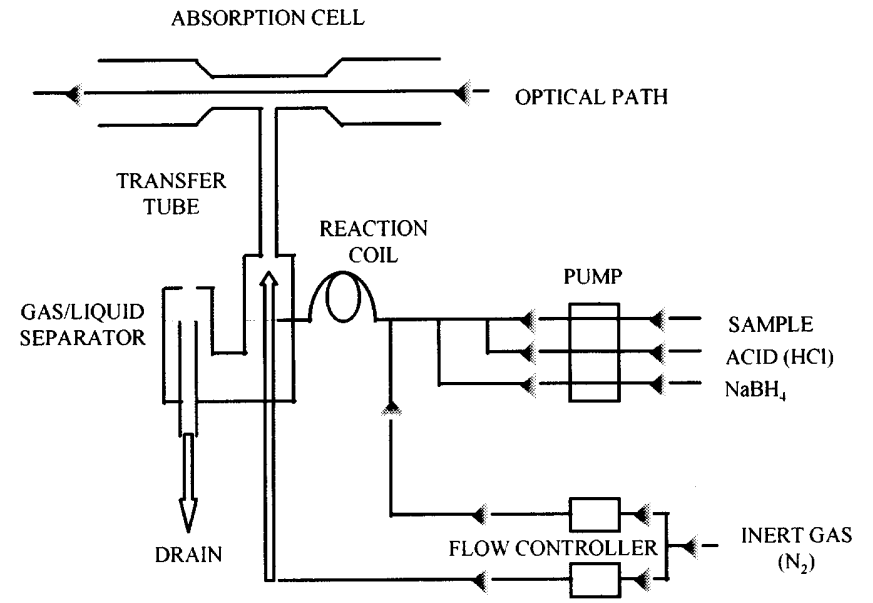

Fig. 1. Schematic diagram of flow injection system for $\mathrm{Hg}$ determination by CVAAS.

Then, samples were ground and sieved through a $63 \mu \mathrm{m}$ mesh sieve. Samples $(0.7 \mathrm{~g})$ were placed into PTFE vessels and $4.5 \mathrm{~mL}$ of $\mathrm{H}_{2} \mathrm{O}$ plus $10 \mathrm{~mL}$ of conc. $\mathrm{HNO}_{3}$ were added. Then, the vessels were capped and heated in a microwave oven $(570 \mathrm{~W}, 8 \mathrm{~min} ; 0 \mathrm{~W}, 3 \mathrm{~min})$. After the extraction programme, the vessels were cooled in a water-bath and opened with the ACM module. The samples were filtered (Whatman No. 41), washed with high purity water and diluted to a final volume of $50 \mathrm{~mL}$.

In all instances the blanks were prepared in parallel and carried out through the procedures in the same manner as the samples.

\section{Procedure}

Figure 1 shows the FI-CVAAS system used in the present work. A solution of $2 \mathrm{M} \mathrm{HCl}\left(1 \mathrm{~mL} \mathrm{~min}{ }^{-1}\right)$ was used in the carrier stream to sweep the sample $\left(7 \mathrm{~mL} \mathrm{~min}{ }^{-1}\right)$ from the injection loop to the mixing coil, where it reacts with the $\mathrm{NaBH}_{4}$ solution $\left(1 \mathrm{~mL} \mathrm{~min}{ }^{-1}\right)$. This reaction produces free $\mathrm{Hg}$ atoms which are separated from the liquid phase in the liquid-gas separator as an atomic vapour. A nitrogen gas stream sweeps the $\mathrm{Hg}$ vapour to a cold quartz absorption cell mounted in the light path of a $\mathrm{Hg}$ hollow cathode lamp in the spectrometer.

Calibration curve was constructed using $\mathrm{Hg}$ standard solutions from 5 to $25 \mathrm{ng} \mathrm{mL}-1$, which were matched in acid concentration to the samples. This aqueous calibration curve was used to directly quantify the samples.

\section{Results and discussion}

\section{Optimization of mercury vapour generation}

\section{Concentration of reductant agent}

$\mathrm{NaBH}_{4}$ is normally preferred as reductant agent because of its advantages, including faster liberation of the $\mathrm{Hg}$ vapour 
from the liquid phase, more efficient attack of the organic $\mathrm{Hg}$ compounds and suitability for including $\mathrm{Hg}$ in multielemental analysis together with other hydride-forming elements [13]. In flow systems the $\mathrm{NaBH}_{4}$ is generally used in lower concentrations $(0.2-0.3 \% \mathrm{~m} / \mathrm{v})[8,15]$ than in batch systems $(3.0-5.0 \% \mathrm{~m} / \mathrm{v})[7,12]$, because the former requires a lower sample volume than the latter.

In order to establish the optimum concentration of this reagent, several concentrations were assayed from $0.0 \%$ to $0.6 \%(\mathrm{~m} / \mathrm{v})$ using a $\mathrm{Hg}$ standard of $20 \mathrm{ng} \mathrm{mL} \mathrm{m}^{-1}$. The acid medium was obtained using $5 \mathrm{M} \mathrm{HCl}$. The results revealed that a maximum and constant absorbance was achieved when the concentration of $\mathrm{NaBH}_{4}$ was higher than $0.1 \%$ $(\mathrm{m} / \mathrm{v})$. Therefore, $0.2 \%(\mathrm{~m} / \mathrm{v})$ was taken as the appropriate concentration. Similar values are recommended in the literature $[15,16]$.

\section{Concentration of acid}

The concentration and type of acid are not critical in the determination of $\mathrm{Hg}$ by CVAAS using $\mathrm{NaBH}_{4}$, only it must be present at a concentration that guarantee the acidity necessary for the $\mathrm{Hg}$ vapour generation. The reduction does not take place in alkaline solution. Generally, the $\mathrm{HCl}$ is the used acid [11]. Nevertheless, it is known that an excessive amount of this acid generates chlorine, which interferes in $\mathrm{Hg}$ determination by CVAAS, absorbing at the $\mathrm{Hg}$ wavelength and suppressing the $\mathrm{Hg}$ response [15].

In order to study the influence of the concentration of $\mathrm{HCl}$ in the analytical $\mathrm{Hg}$ signal, it was assayed from 0 to $9 \mathrm{M}$. No significant differences were observed for the results obtained for a $\mathrm{Hg}$ standard of $20 \mathrm{ng} \mathrm{mL}^{-1}$, probably due to the amount of nitric acid previously added to the matrixmatched standards. A concentration of $2 \mathrm{M} \mathrm{HCl}$ was chosen as a convenient level.

\section{Time of reaction}

The time of reaction was defined as the time necessary to achieve a stable $\mathrm{Hg}$ signal, corresponding to an efficient atomic vapour generation. There are not many studies in the literature regarding this parameter [8].

Different times were assayed, between 0 and $100 \mathrm{~s}$, to measure a $\mathrm{Hg}$ standard of $20 \mathrm{ng} \mathrm{mL}^{-1}$ using $2 \mathrm{M} \mathrm{HCl}$ and $0.2 \%(\mathrm{~m} / \mathrm{v}) \mathrm{NaBH}_{4}$. The absorbance was maximal (Fig. 2) when the reaction time ranged from 60 to100 s; then, $60 \mathrm{~s}$ was selected in order to minimize the time of the analysis.

The operational conditions established for the $\mathrm{Hg}$ vapour generation are summarized in table I.

\section{Interferences}

In the CVAAS technique chemical interferences caused by other elements present in samples belong to be the most serious. Particularly, those elements that suffer a reduction to metals and form amalgams such as Ag, Au, Pt and Pd. Also, must be taken into account other elements, like as $\mathrm{Cu}, \mathrm{Pb}$, and $\mathrm{Ni}$, when $\mathrm{NaBH}_{4}$ is used in the reduction stage [12].

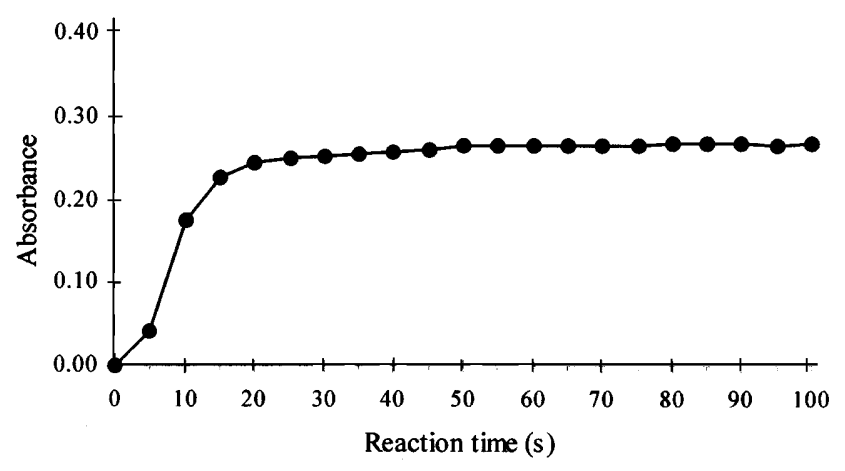

Fig. 2. Influence of the reaction time on the $\mathrm{Hg}$ signal.

Table I. Analytical conditions for the $\mathrm{Hg}$ vapour generation.

\begin{tabular}{lc}
\hline Reductant Concentration & $0.2 \%(\mathrm{~m} / \mathrm{v}) \mathrm{NaBH}_{4}$ \\
\hline Reductant Flow & $1 \mathrm{~mL} \mathrm{~min}^{-1}$ \\
Carrier Concentration & $2 \mathrm{M} \mathrm{HCl}$ \\
Carrier Flow & $1 \mathrm{~mL} \mathrm{m^{-1 }}$ \\
Sample Flow & $7 \mathrm{~mL} \mathrm{~min}^{-1}$ \\
Reaction Time & $60 \mathrm{~s}$ \\
\hline
\end{tabular}

The flow system exhibits a better tolerance towards hydride forming elements than the batch system, due to the shorter reaction time and the smaller sample volume. Thus, the interfering transition metal ions could not be reduced to metal, which could then not interfere [14].

Several studies have been focused on the investigation of the interferences in $\mathrm{Hg}$ analysis by CVAAS. BERNTH and VELDEBO [9] observed that $\mathrm{Cu}(\mathrm{II}), \mathrm{Ni}(\mathrm{II}), \mathrm{Pb}(\mathrm{II})$ and $\mathrm{Ag}(\mathrm{I})$ seriously suppressed the response of $\mathrm{Hg}$ when $\mathrm{NaBH}_{4}$ was used as the reductant. EL-DEFRAWY [11] observed than the presence of $\mathrm{Ag}(\mathrm{I}), \mathrm{Au}(\mathrm{III}), \mathrm{Pt}(\mathrm{II}), \mathrm{Pd}(\mathrm{II}), \mathrm{Rh}(\mathrm{III}), \mathrm{Ru}(\mathrm{III})$, $\mathrm{Co}(\mathrm{II}), \mathrm{Cu}(\mathrm{II}), \mathrm{Ni}(\mathrm{II})$ and $\mathrm{Pb}$ (II) at concentrations of $40 \mu \mathrm{g} \mathrm{mL}-1$ cause interference on $\mathrm{Hg}$ determination. However, SZMYD et al. [12] did not detect interferences by $\mathrm{Cu}(\mathrm{II}), \mathrm{Pb}(\mathrm{II})$ and $\mathrm{As}(\mathrm{V})$, but the effect produced by $\mathrm{Ag}(\mathrm{I})$, $\mathrm{Au}(\mathrm{III}), \mathrm{Pt}(\mathrm{II}), \mathrm{Pd}(\mathrm{II})$ and $\mathrm{Se}(\mathrm{IV})$ was important. MADRID et al. [13] found that $\mathrm{Cd}(\mathrm{II})$ and $\mathrm{Pb}(\mathrm{II})$ do not interfere, although $\mathrm{Se}(\mathrm{IV}), \mathrm{Ni}(\mathrm{II})$ and $\mathrm{Cu}(\mathrm{II})$ depressed significantly the analytical signal of $\mathrm{Hg}$. PSZOINCKI et al. [10] investigated several ions and detected negative influence of $\mathrm{Cu}(\mathrm{II})$, $\mathrm{Ag}(\mathrm{I}), \mathrm{Se}(\mathrm{IV}), \mathrm{Au}(\mathrm{III}), \mathrm{Pd}(\mathrm{II})$ and $\mathrm{Te}(\mathrm{IV})$ on the analytical signal of $\mathrm{Hg}$, at low concentrations. They used successfully the successive dilution method to eliminate these interferent effects.

Applying the procedure established above (Tab. I), the study of the effect of several ions on the determination of $\mathrm{Hg}$ by CVAAS, was carried out. The ions investigated and the signal variation registered (in percentage) are listed in table II. 


\section{Original articles}

Table II. Influence of different spiked species (at three levels of concentration) on the absorbance of $\mathrm{Hg}\left(10 \mathrm{ng} \mathrm{mL}^{-1}\right)$. The figures indicate the percentage of enhancement $(+)$ or depression $(-)$ of the signal.

\begin{tabular}{lccc}
\hline Ion & \multicolumn{3}{c}{ Interferent concentration $\left(\mu \mathrm{g} \mathrm{mL}^{-1}\right)$} \\
& 10 & 100 & 500 \\
\hline $\mathrm{Al}^{3+}$ & +5 & +3 & -- \\
$\mathrm{Ca}^{2+}$ & -- & +1 & +9 \\
$\mathrm{Co}^{2+}$ & -4 & -11 & -- \\
$\mathrm{Fe}^{2+}$ & +2 & +2 & +4 \\
$\mathrm{~K}^{+}$ & -- & +2 & +11 \\
$\mathrm{Mg}^{2+}$ & -2 & +3 & -- \\
$\mathrm{Mn}^{2+}$ & -1 & +5 & -- \\
$\mathrm{Na}^{+}$ & -- & 0 & +2 \\
$\mathrm{~Pb}^{2+}$ & -2 & 0 & -- \\
$\mathrm{Zn}^{2+}$ & -1 & -1 & -- \\
$\mathrm{Cl}^{-}$ & -- & +3 & +3 \\
$\mathrm{CO}_{3}{ }^{2-}$ & -- & 0 & -10 \\
$\mathrm{NO}_{3}{ }^{2-}$ & 0 & 0 & -- \\
$\mathrm{PO}_{4}{ }^{2-}$ & +1 & 0 & -- \\
$\mathrm{SO}_{4}{ }^{2-}$ & +2 & +2 & -- \\
\hline
\end{tabular}

Here, the interferent effect was considered to be significant when the absorbance variation signal is more than $\pm 10 \%$. As can be seen, no significant variation was recorded at the concentrations studied of interfering ions, which correspond to levels much higher than those usually found in sediment extracts [17].

A separate study was needed to evaluate the effect of $\mathrm{Cu}^{2+}$ and $\mathrm{Ni}^{2+}$ on the $\mathrm{Hg}$ signal. $\mathrm{Hg}$ absorbance (10 $\mathrm{ng}$ $\mathrm{mL}^{-1}$ ) was significantly diminished $(>35 \%)$ by $\mathrm{Cu}^{+2}$ and $\mathrm{Ni}^{+2}$ at concentrations above $2 \mu \mathrm{g} \mathrm{mL} \mathrm{m}^{-1}$ and $20 \mu \mathrm{g} \mathrm{mL}^{-1}$, respectively. These results are in concordance with other previously reported $[9,11,13]$. It is important to note that these values are higher than those found in the acid extracts of sediments $\left(\leq 0.49 \mu \mathrm{g} \mathrm{mL}{ }^{-1}\right.$ or $35 \mu \mathrm{g} \mathrm{g}^{-1}$ for $\mathrm{Cu}$ and $0.77 \mu \mathrm{g}$ $\mathrm{mL}^{-1}$ or $55 \mu \mathrm{g} \mathrm{g}^{-1}$ for $\mathrm{Ni}$ ), being not necessary the addition of reagents to eliminate these interferences.

\section{Analytical figures of merit}

The analytical response was linear from 0 to $70 \mathrm{ng} \mathrm{mL}^{-1}$ of $\mathrm{Hg}$, and the working range employed was $0-25 \mathrm{ng} \mathrm{mL}^{-1}$ of $\mathrm{Hg}$. In order to confirm the absence of matrix effects standard-addition calibration graphs were also run. The regression lines obtained were $A=0.0144[\mathrm{Hg}]-0.0006$ $(r=0.9999)$ and $A=0.0143[\mathrm{Hg}]+0.0443(r=0.9999)$ for aqueous calibration and standard addition graphs, respectively. No statistical differences (at $95 \%$ confidence interval) were found between both slopes. This confirms the absence of matrix interferences in the determination of $\mathrm{Hg}$ in sediment acid extracts by CVAAS applying the established operational conditions.
The detection limit, defined as the $\mathrm{Hg}$ concentration corresponding to three times the standard deviation of ten measurements of the blanks, was $0.11 \mathrm{ng} \mathrm{mL}^{-1}$ and $0.01 \mu \mathrm{g} \mathrm{g}^{-1}$.

The method validation was performed analyzing a certified reference sediment, BCR CRM 277 Estuarine Sediment (Hg certified content: $1.77 \pm 0.06 \mu \mathrm{g} \mathrm{g}^{-1}$ ). Six aliquots were taken, microwave-extracted and then analyzed by triplicate. The mean value ( \pm standard deviation) obtained was $1.73 \pm$ $0.04 \mu \mathrm{g} \mathrm{g}^{-1}$. The recovery was calculated as obtained value/certified value. All recoveries were satisfactory, ranging $94-102 \%$. The precision, expressed as relative standard deviation (RSD), also was good $(<3 \%, n=6)$.

\section{Analysis of estuarine sediments}

The proposed method was applied to the determination of $\mathrm{Hg}$ content in six samples of surface sediments from AresBetanzos Estuary (Galicia, NW Spain). Sampling points were situated at near-shore zones (\# 1,2,3) and in the middle of the estuary (\# 4, 5, 6); the following $\mathrm{Hg}$ concentrations were obtained, respectively: $0.16,0.12,0.44,0.11,0.21$ and $0.31 \mu \mathrm{g} \mathrm{g}^{-1}$. These values are below than the limit established by the EPA [18] for heavily polluted sediments $\left(1 \mu \mathrm{g} \mathrm{g}^{-1}\right)$ but of similar magnitude to the levels found in other near-shore sediments of the world [19].

\section{Conclusion}

The method established, using a FI-CVAAS system and $\mathrm{NaBH}_{4}$ as reductant agent, was found to be very accurate, precise and exhibiting a high sensitivity for the analysis of $\mathrm{Hg}$ in marine sediments after microwave extraction with nitric acid in closed vessels. Only $\mathrm{Cu}^{2+}$ and $\mathrm{Ni}^{2+}$ caused serious interferences, but at concentrations higher than those usually found in sediment extracts. The levels of $\mathrm{Hg}$ found in the analyzed samples corresponded to uncontaminated sediments.

\section{Acknowledgements}

M.L. Martínez wishes to thank the Education and Culture Ministry of Spain for the award of a research studentship to read for a Ph.D. degree (B.O.E. No. 171, 19-7-93). The authors thank NORCONTROL, S.A. for the help received in support of this work.

\section{References}

1. Massard, E. J., The Developmental Cytotoxicity of Mercurials. In: Toxicology of Metals, Lewis Publishers, Florida, 1996; Chapter 66 pp 1047-1081.

2. Van Delft, W.; Vos, G. Anal. Chim. Acta. 1988, 209, 147-156.

3. Tanaka, H.; Kouno, M.; Morita, H.; Okamoto, K.; Shimomura, S. Anal. Sci. 1992, 8, 857- 861.

4. Liang, L.; Horvat, M.; Cernichiari, E.; Gelein, B.; Balogh, S. Talanta 1996, 43, 1883-1888. 


\section{Original articles}

5. Brown, R.; Gray, D. J.; Tye, D. Water Air Soil Pollut. 1995, 80, 1237-1245.

6. Bermejo-Barrera, P.; Moreda-Pineiro, J.; Moreda-Pineiro, A.; Bermejo-Barrera, A. Mikrochim. Acta 1996, 124, 111-122.

7. Welz, B.; Schubert-Jacobs, M. Fresenius Z. Anal. Chem. 1988, 331, 324-329.

8. Evans, S. J.; Johnson, M. S.; Leah, R. T. Varian Instruments at Work 1986, No. AA-60; pp 1-6.

9. Bernth, N.; Vendelbo, K. Analyst 1984, 109, 309-311.

10. Pszonicki, L.; Skwara, W.; Dudek, J. Chem. Anal. (Warsaw) 1994, 39, 205-215.

11. El-Defrawy, M. M. Analusis 1993, 21, 91-93.

12. Szmyd, E.; Baranowka, I. Fresenius J. Anal. Chem. 1994, 350, 178-180.
13. Madrid, Y.; Gutierrez, J. M.; Camara, C. Spectrochim. Acta 1994, 49B(2), 163-170.

14. Samanta, G.; Chakraborti, D. Fresenius J. Anal. Chem. 1997, 357, 827-832.

15. Zhou, C. Y.; Wong, M. K.; Koh, L. L.; Wee, Y. C. Anal. Sci. 1996, 12, 471-476.

16. Schnitzer, G.; Soubelet, A.; Testu, C.; Chafey, C. Mikrochim. Acta. 1995, 119, 199-209.

17. Bowen, H. J. M. The Elemental Geochemistry of Rocks. In: Environmental Chemistry of the Elements, Academic Press Inc, London, 1979; pp 31-48.

18. Nichols, S. J.; Manny, B. A.; Schloesser, D. W.; Edsall, T. A. Hydrobiol. 1991, 219, 307-315.

19. Haynes, D.; Toohey, D.; Clarke, D.; Marney, D. Mar. Pollut. Bull. 1995, 30(6), 414-418. 